\title{
Nickel Thiolate Complexes as Ligands for Copper and Zinc: Novel Additions to a Library of Binding Modes
}

\author{
Johanna A. W. Verhagen, ${ }^{[a]}$ Christian Tock, ${ }^{[a]}$ Martin Lutz, ${ }^{[b]}$ Anthony L. Spek, ${ }^{[b]}$ and \\ Elisabeth Bouwman*[a]
}

Keywords: Nickel / Copper / Zinc / S ligands / Cluster compounds

The reactivity of the two nickel complexes [Ni(xbsms)] and [Ni(bsms) $\left.)_{2}\right]\left[\mathrm{H}_{2} \mathrm{xbsms}=\alpha, \alpha^{\prime}\right.$-bis(4-mercapto-3,3-dimethyl-2thiabutyl)-o-xylene; Hbsms = 4-mercapto-3,3-dimethyl-1phenyl-2-thiabutane] towards copper iodide and zinc bromide has been investigated. The reactions yield novel aggregates of higher nuclearity with topologies that are different from previous reports; the nickel complexes in all cases can be considered as didentate $\mathrm{S}$ ligands. The X-ray structure of the novel octanuclear cluster $\left[\left\{\mathrm{Ni}(\mathrm{bsms})_{2}\right\}_{3}(\mathrm{CuI})_{5}\right]$ shows a unique arrangement in which the cis- $\mathrm{NiS}_{2} \mathrm{~S}_{2}{ }_{2}$ units act as didentate ligands to a trigonal-bipyramidal array of five $\mathrm{Cu}^{\mathrm{I}}$ ions. The tetranuclear structure of $\left[\{\mathrm{Ni}(\mathrm{xbsms}) \mathrm{CuI}\}_{2}\right]$ shows unprecedented asymmetric bridging of the thiolate sulfur atoms, with one of the thiolate groups binding to one copper ion and the other one $\mu_{3}$-bridging to two copper ions. The complex is located on a crystallographic twofold axis and the complex in a single crystal is enantiomerically pure. The trinuclear complex $\left[\mathrm{Ni}_{2}(\mathrm{bsms})_{3} \mathrm{ZnBr}_{3}\right]$ is formed as a result of dissociation of the didentate bsms ligand from part of the mononuclear complex and reassembly to form a dinuclear core to which the $\mathrm{ZnBr}_{3}{ }^{-}$unit is coordinated to a single thiolate sulfur atom. A complex of stoichiometry $\left[\mathrm{Ni}_{3}(\mathrm{xbsms})_{2}\right.$ $\left(\mathrm{ZnBr}_{3}\right)_{2}$ ] has also been isolated and a structure proposal based on spectroscopic properties is given. All complexes have been characterised by analytical and spectroscopic methods.

( Wiley-VCH Verlag GmbH \& Co. KGaA, 69451 Weinheim, Germany, 2006)

\section{Introduction}

It is now generally accepted that the A-cluster of acetylcoenzyme-A-synthase/CO-dehydrogenase (ACS/CODH) in its active state contains a dinuclear nickel site bound to an iron-sulfur cluster ${ }^{[1]}$ However, due to the earlier reports of $\mathrm{Cu}$ - or Zn-containing structures, ${ }^{[2,3]}$ attempts to synthesise structural models of the A-cluster have resulted in reports of several new heteronuclear clusters. ${ }^{[4-11]}$ In most of these investigations, discrete mononuclear nickel complexes of tetradentate $\mathrm{N}_{2} \mathrm{~S}_{2}$ ligands have been used as building blocks, and their reactivity towards transition metals such as $\mathrm{Fe}, \mathrm{Ni}, \mathrm{Cu}, \mathrm{Zn}, \mathrm{Ag}, \mathrm{Pd}$ and $\mathrm{Hg}$ have been studied. The nickel complexes can be considered to react as didentate $\mathrm{S}$ ligands. A wealth of structures has become available, and a range of possible bridging modes for the thiolate sulfur atoms have been reported. ${ }^{[7]}$ The two cis-thiolate sulfur atoms in the parent nickel complex may form single bridges to two different metal ions in, for example, $\mathrm{Ni}_{3} \mathrm{Cu}_{2}, \mathrm{Ni}_{3} \mathrm{Ag}_{2}$ or $\mathrm{Ni}_{3} \mathrm{Zn}_{2}$ clusters ${ }^{[4,10,12,13]}$ or $\mathrm{Ni}_{4} \mathrm{Pd}_{2}$ paddle wheels; ${ }^{[10,14]}$ they can act as a chelating ligand to one metal ion to form

[a] Leiden Institute of Chemistry, Gorlaeus Laboratories, Leiden University,

P. O. Box 9502, 2300 RA Leiden, The Netherlands

Fax: +31-71-527-4550

E-mail: bouwman@chem.leidenuniv.nl

[b] Bijvoet Center for Biomolecular Research, Crystal and Structural Chemistry, Utrecht University,

Utrecht, The Netherlands discrete $\mathrm{NiCu}$ or $\mathrm{NiNi}$ dinuclear complexes ${ }^{[4,5,8,11]}$ or linear trinuclear $\mathrm{Ni}_{3}$ or $\mathrm{Ni}_{2} \mathrm{Cu}$ complexes; ${ }^{[8,15]}$ or they may bind to four different metal ions through $\mu_{3}-\mathrm{S}$ bridges in larger $\mathrm{Ni}_{2} \mathrm{Cu}_{4}$ aggregates. ${ }^{[16]}$ The nuclearity of the cluster and type of aggregate that is formed is largely dependent on the stoichiometry of the reactants and the presence or absence of coordinating anions. In all of these clusters the nickel ion in the parent complex remains divalent and low-spin in a square-planar geometry. However, when using flexible ligands that allow for different geometries, in a reaction with low-valent metal centres the nickel ion may be reduced and expelled from the ligand ${ }^{[17,18]}$ or it may result in clusters in which the nickel centre is coordinated by the ligand in a tetrahedral geometry and in which additional metal-metal bonds are formed. ${ }^{[19,20]}$

Numerous $\mathrm{Cu}^{\mathrm{I}}$ thiolate clusters have been reported. Homoleptic $\mathrm{Cu}^{\mathrm{I}}$ clusters with monodentate thiolate ligands have been reported as $\left[\mathrm{Cu}_{4}(\mathrm{SR})_{4}\right]$ in a square-planar or cubane arrangement, as $\left[\mathrm{Cu}_{4}(\mathrm{SR})_{6}\right]$ in a tetrahedral or adamantane arrangement, or as clusters of varying stoichiometry such as $\left[\mathrm{Cu}_{5}(\mathrm{SR})_{6}\right],\left[\mathrm{Cu}_{5}(\mathrm{SR})_{7}\right],\left[\mathrm{Cu}_{6}(\mathrm{SR})_{6}\right],\left[\mathrm{Cu}_{8}(\mathrm{SR})_{8}\right]$, $\left[\mathrm{Cu}_{8}(\mathrm{SR})_{12}\right]$ and $\left[\mathrm{Cu}_{12}(\mathrm{SR})_{12}\right] \cdot{ }^{[21]}$ In addition, some $\mathrm{Cu}^{\mathrm{I}}$ clusters containing dithiolate ligands have been reported. ${ }^{[22]}$ The central cores in these homoleptic clusters are remarkably similar to the heteronuclear clusters that can be obtained with the nickel complexes, in which the $\left[\mathrm{NiN}_{2} \mathrm{~S}_{2}\right]$ group acts as a didentate sulfur ligand. 
Earlier we have synthesised nickel complexes as models for hydrogenases by making use of various ligands containing oxygen, nitrogen and sulfur donor atoms. ${ }^{[23-25]}$ The reactivity of these nickel complexes with various iron sources has resulted in novel compounds, in some cases of surprising composition. ${ }^{[17-19]}$ Recently, we have reported the mononuclear complexes $\left[\mathrm{Ni}(\mathrm{bsms})_{2}\right]$ and $[\mathrm{Ni}(\mathrm{xbsms})]$ in which the nickel ion is in an $\mathrm{S}_{4}$ coordination environment $\left[\mathrm{H}_{2} \mathrm{xbsms}=\alpha, \alpha^{\prime}\right.$-bis(4-mercapto-3,3-dimethyl-2-thiabutyl)$o$-xylene; Hbsms = 4-mercapto-3,3-dimethyl-1-phenyl-2thiabutane]. ${ }^{[26]}$ The reactivity of these mononuclear complexes towards nickel and iron has been studied and the trinuclear nickel complexes $\left[\mathrm{Ni}_{3}(\mathrm{bsms})_{4}\right]\left(\mathrm{BF}_{4}\right)_{2}$ and $\left[\mathrm{Ni}_{3}-\right.$ (xbsms $\left.)_{2}\right]\left(\mathrm{BF}_{4}\right)_{2}$ have been reported. ${ }^{[15,27]}$

The reactivity of these complexes towards copper(I) and zinc(II) salts has now been investigated, resulting in a number of novel aggregates with unprecedented structures that are described below.

\section{Results}

\section{Reactivity Studies}

The reactivity of the mononuclear $\mathrm{NiS}_{4}$ complex [Ni(xbsms)] towards $\mathrm{FeCl}_{2},\left[\mathrm{Fe}_{2}(\mathrm{CO})_{9}\right]$ and $\left[\mathrm{Fe}(\mathrm{CO})_{2}(\mathrm{NO})_{2}\right]$ appeared to be very similar to that reported for $\mathrm{NiN}_{2} \mathrm{~S}_{2}$ complexes, ${ }^{[28]}$ with the nickel complex acting as a monodentate or didentate chelating ligand to iron. Despite the trans orientation of the two didentate ligands in [Ni(bsms) $)_{2}$ ] a similar reactivity towards $\mathrm{FeCl}_{2}$ has been observed; ${ }^{[15]}$ in aggregation reactions with nickel or iron the two ligands tend to rearrange to form a nickel complex with the cis-dithiolate conformation required for further binding. The reactivity of the mononuclear complexes [Ni(xbsms)] and $\left[\mathrm{Ni}(\mathrm{bsms})_{2}\right]$ has now been investigated in reactions with $\mathrm{ZnBr}_{2}, \mathrm{ZnCl}_{2}$ and $\mathrm{CuI}$, with acetonitrile as the solvent and in 1:1 molar ratios; interesting new products of unexpected stoichiometries have been obtained (Scheme 1). The reactivity of the complexes towards $\mathrm{ZnBr}_{2}$ and $\mathrm{ZnCl}_{2}$ appeared to be similar as analogous products were obtained; only the results of the reactions with $\mathrm{ZnBr}_{2}$ are reported.

Reactions of the related trinuclear nickel complexes $\left[\mathrm{Ni}_{3}(\mathrm{xbsms})_{2}\right]\left(\mathrm{BF}_{4}\right)_{2}$ and $\left[\mathrm{Ni}_{3}(\mathrm{bsms})_{4}\right]\left(\mathrm{BF}_{4}\right)_{2}$ with either $\mathrm{CuI}$ or $\mathrm{ZnBr}_{2}$ did not generate any new compounds of different stoichiometries. The trinuclear complexes appeared to be relatively inert, and the starting materials could be recovered from most of the reactions.

\section{Structures of the Complexes}

\section{Structure of $\left[\left\{\mathrm{Ni}(\mathrm{bsms})_{2}\right\}_{3}(\mathrm{CuI})_{5}\right]$ (1)}

The asymmetric unit contains two independent molecules of $\left[\left\{\mathrm{Ni}(\mathrm{bsms})_{2}\right\}_{3}(\mathrm{CuI})_{5}\right]$ together with four acetone molecules and two diethyl ether molecules. The differences between the two independent molecules are very small, therefore the detailed geometry of only one of them is discussed. An ORTEP projection of the structure of $\left[\left\{\mathrm{Ni}(\mathrm{bsms})_{2}\right\}_{3}(\mathrm{CuI})_{5}\right]$ is shown in Figure 1. Another projection showing the coordination environment of the nickel and copper centres is given in Figure 2. Crystal data are given in the Experimental Section and selected bond lengths and angles are summarised in Table 1. Three square-planar nickel(II) centres, three trigonal-planar copper(I) ions and two tetrahedrally coordinated copper(I) ions constitute the octanuclear cluster. The nickel ions have an $\mathrm{S}_{2} \mathrm{~S}_{2}{ }_{2}$ coordination, with the coordination environment consisting of two didentate bsms ligands that bind through the thiolate groups in the cis positions. The trigonal-planar copper ions have an $\mathrm{S}_{2} \mathrm{I}$ coordination environment and the tetrahedral copper ions are in an $\mathrm{S}_{3} \mathrm{I}$ coordination environment.
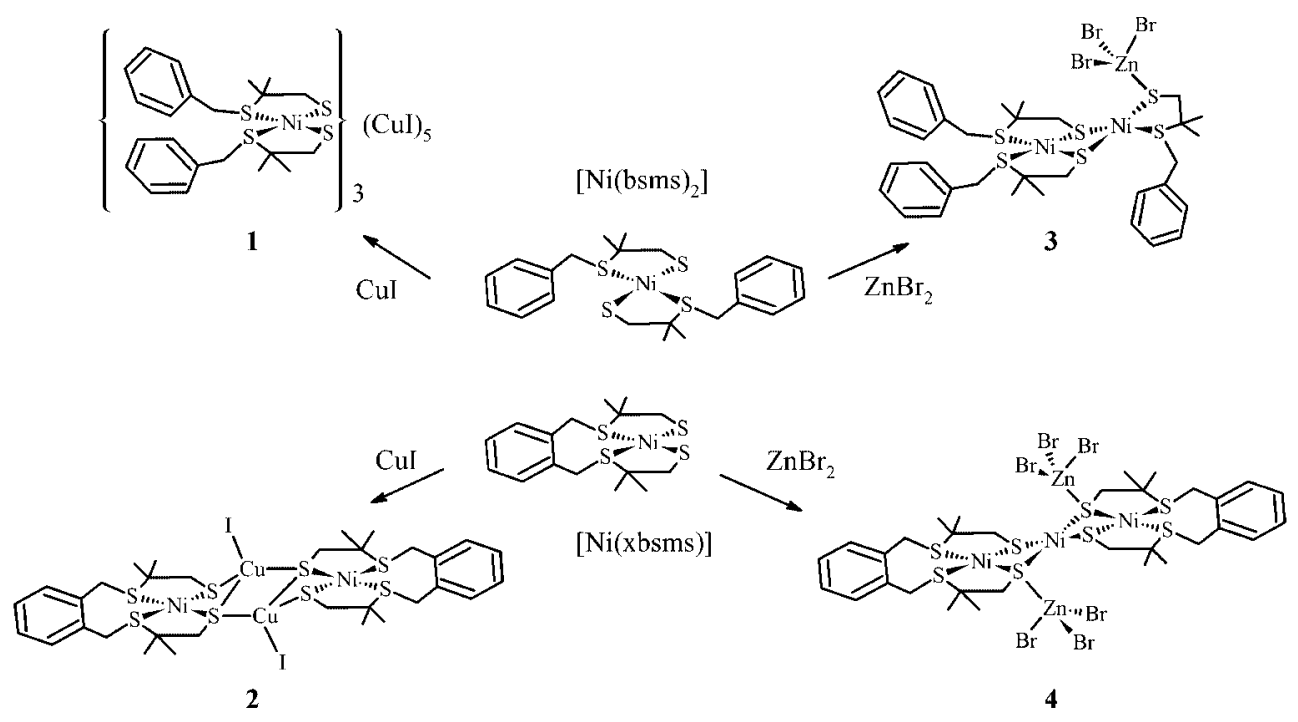

Scheme 1. Synthesis of the novel clusters. 


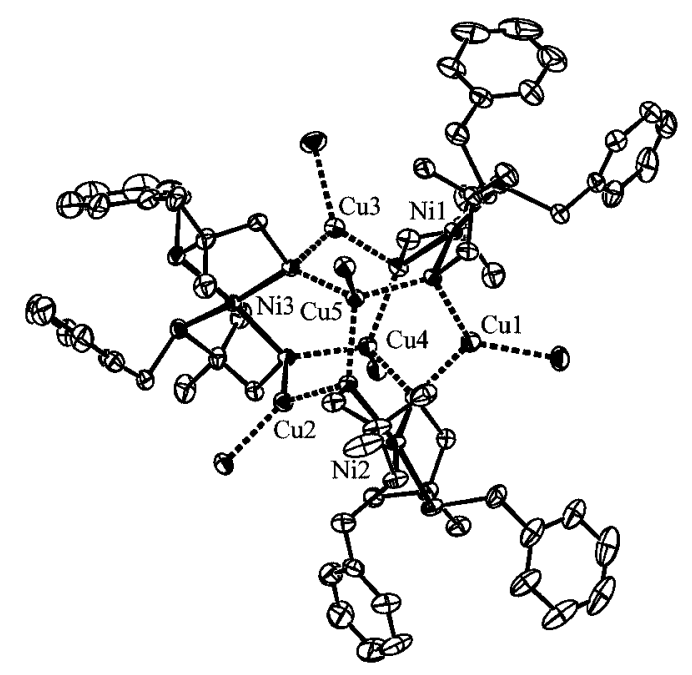

Figure 1. Displacement ellipsoid plot of one of the independent molecules of $\left[\left\{\mathrm{Ni}(\mathrm{bsms})_{2}\right\}_{3}(\mathrm{CuI})_{5}\right](\mathbf{1})$, drawn at the $50 \%$ probability level. Hydrogen atoms and the solvent molecules have been omitted and copper surroundings are indicated by dashed bonds for clarity.

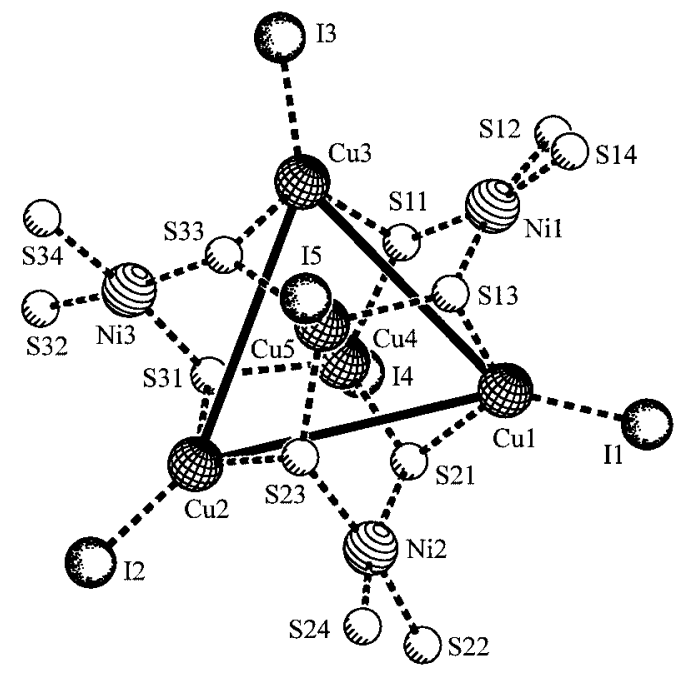

Figure 2. Projection of the central core and the coordination environment of the copper and nickel centres in $\mathbf{1}$. View approximately along the pseudo-threefold axis of the trigonal bipyramid; the trigonal plane is indicated by solid lines.

The five copper ions are clustered in a trigonal-bipyramidal array, with the three trigonal-planar copper ions in the equatorial plane and the tetrahedral copper ions at the apices. The $\mathrm{NiS}_{2} \mathrm{~S}_{2}$ units are each capping two edges of the trigonal bipyramid with two $\mu_{3}$-bridging thiolate groups that each connect two copper ions with one nickel ion; each nickel complex thus binds to four different copper ions. Each nickel dithiolate complex bridges two equatorial copper ions to form a giant twelve-membered $\mathrm{Ni}_{3} \mathrm{Cu}_{3} \mathrm{~S}_{6}$ ring. The tetrahedral copper ions are coordinated to three thiolate groups, each from a different $\mathrm{NiS}_{2} \mathrm{~S}_{2}{ }_{2}$ unit, thus capping the 12-membered crown on both sides, and as a result creating a cage. All thiolate sulfur atoms use three lone pairs in a distorted tetrahedral geometry in binding to one nickel
Table 1. Selected bond lengths $[\AA ̊]$ and angles $\left[{ }^{\circ}\right]$ in $\left[\left\{\mathrm{Ni}(\mathrm{bsms})_{2}\right\}_{3^{-}}\right.$ $\left.(\mathrm{CuI})_{5}\right](\mathbf{1})$.

\begin{tabular}{llll}
\hline $\mathrm{Cu}(4) \cdots \mathrm{Cu}(5)$ & $4.2012(12)$ & $\mathrm{Cu}(1) \cdots \mathrm{Cu}(4)$ & $3.5855(12)$ \\
$\mathrm{Cu}(1) \cdots \mathrm{Ni}(1)$ & $3.1381(13)$ & $\mathrm{Ni}(1) \cdots \mathrm{Ni}(2)$ & $6.1880(15)$ \\
$\mathrm{Ni}(1)-\mathrm{S}(11)$ & $2.1868(17)$ & $\mathrm{Ni}(1)-\mathrm{S}(12)$ & $2.2010(19)$ \\
$\mathrm{Ni}(1)-\mathrm{S}(13)$ & $2.1970(18)$ & $\mathrm{Ni}(1)-\mathrm{S}(14)$ & $2.1966(18)$ \\
$\mathrm{Cu}(1)-\mathrm{S}(13)$ & $2.2481(18)$ & $\mathrm{Cu}(4)-\mathrm{S}(11)$ & $2.3252(18)$ \\
$\mathrm{Cu}(1)-\mathrm{S}(21)$ & $2.2775(18)$ & $\mathrm{Cu}(4)-\mathrm{S}(21)$ & $2.3548(18)$ \\
$\mathrm{Cu}(1)-\mathrm{I}(1)$ & $2.4903(10)$ & $\mathrm{Cu}(4)-\mathrm{S}(31)$ & $2.3354(18)$ \\
& & $\mathrm{Cu}(4)-\mathrm{I}(4)$ & $2.5801(9)$ \\
$\mathrm{S}(13)-\mathrm{Cu}(1)-\mathrm{S}(21)$ & $110.34(7)$ & $\mathrm{S}(11)-\mathrm{Ni}(1)-\mathrm{S}(12)$ & $91.64(7)$ \\
$\mathrm{S}(13)-\mathrm{Cu}(1)-\mathrm{I}(1)$ & $130.85(5)$ & $\mathrm{S}(11)-\mathrm{Ni}(1)-\mathrm{S}(13)$ & $91.15(6)$ \\
$\mathrm{S}(21)-\mathrm{Cu}(1)-\mathrm{I}(1)$ & $118.73(5)$ & $\mathrm{S}(11)-\mathrm{Ni}(1)-\mathrm{S}(14)$ & $169.77(8)$ \\
$\mathrm{S}(11)-\mathrm{Cu}(4)-\mathrm{S}(21)$ & $106.79(6)$ & $\mathrm{S}(12)-\mathrm{Ni}(1)-\mathrm{S}(13)$ & $169.19(8)$ \\
$\mathrm{S}(11)-\mathrm{Cu}(4)-\mathrm{S}(31)$ & $115.73(7)$ & $\mathrm{S}(12)-\mathrm{Ni}(1)-\mathrm{S}(14)$ & $87.84(7)$ \\
$\mathrm{S}(11)-\mathrm{Cu}(4)-\mathrm{I}(4)$ & $105.31(5)$ & $\mathrm{S}(13)-\mathrm{Ni}(1)-\mathrm{S}(14)$ & $91.25(7)$ \\
$\mathrm{S}(21)-\mathrm{Cu}(4)-\mathrm{S}(31)$ & $104.64(7)$ & $\mathrm{Cu}(1)-\mathrm{S}(13)-\mathrm{Cu}(5)$ & $112.11(7)$ \\
$\mathrm{S}(21)-\mathrm{Cu}(4)-\mathrm{I}(4)$ & $113.42(5)$ & $\mathrm{Cu}(1)-\mathrm{S}(13)-\mathrm{Ni}(1)$ & $89.81(6)$ \\
$\mathrm{S}(31)-\mathrm{Cu}(4)-\mathrm{I}(4)$ & $111.11(5)$ & $\mathrm{Cu}(5)-\mathrm{S}(13)-\mathrm{Ni}(1)$ & $129.75(8)$ \\
\hline
\end{tabular}

ion and two copper ions. Finally, the coordination environment of each copper ion is completed by one iodide ion.

The molecule lacks crystallographic symmetry elements and therefore every nickel centre and every copper centre is unique. However, the molecule contains an approximate, non-crystallographic threefold rotation axis running through the apical copper ions that makes the differences between the three nickel ions, the three equatorial copper ions $\mathrm{Cu}_{\text {eq }}$ and the two tetrahedrally coordinated copper ions $\mathrm{Cu}_{\mathrm{ap}}$ very small. The nickel-thiolate distances vary from 2.082(17) to 2.1861(18) $\AA$, and are comparable to the distances found in the starting complex $\left[\mathrm{Ni}(\mathrm{bsms})_{2}\right]$, and the nickel-thioether distances are 2.1966(18)-2.2108(19) A, slightly longer than those in $\left[\mathrm{Ni}(\mathrm{bsms})_{2}\right]^{[26]}{ }^{26} \mathrm{The} \mathrm{Cu}_{\text {eq }}$-thiolate distances vary from 2.2328(19) to 2.2775(18) A, whereas the $\mathrm{Cu}_{\mathrm{ap}}$-thiolate distances are slightly longer and vary from $2.3204(18)$ to $2.3548(18) \AA$. The $\mathrm{Cu}_{\mathrm{eq}}$-iodide distances are 2.4860(10)-2.4903(10) $\AA$ and the $\mathrm{Cu}_{\mathrm{ap}}$-iodide distances are 2.5775(9)-2.5801(9) $\AA$. Because of the rigid conformation of the complex the nickel centres have a tetrahedral distortion with a dihedral angle varying from $12.09(10)$ to $18.44(10)^{\circ}$ between the planes $\mathrm{S}(\mathrm{n} 1)-\mathrm{Ni}(\mathrm{n})-$ $\mathrm{S}(\mathrm{n} 2)$ and $\mathrm{S}(\mathrm{n} 3)-\mathrm{Ni}(\mathrm{n})-\mathrm{S}(\mathrm{n} 4)$. The geometry around the $\mathrm{Cu}_{\text {eq }}$ ions deviates only slightly from planarity and the angles around the tetrahedral $\mathrm{Cu}_{\mathrm{ap}}$ ions are in the range 104.64(7)-115.73(7) ${ }^{\circ}$.

The intramolecular $\mathrm{Cu} \cdots \mathrm{Cu}$ contacts vary from 3.4668(13) to 5.3666(14) $\AA$, with the shortest distances between the apical and equatorial copper ions. The distances between the nickel centres range from 6.0776(15) to 6.3023(14) A.

Although the nickel(II) ions in the solid structure have a significant tetrahedral distortion, in solution the $\mathrm{Ni}^{\mathrm{II}}$ ions are in a low-spin state, as shown by NMR experiments. In the ${ }^{1} \mathrm{H}$ NMR spectrum of the complex in $\left[\mathrm{D}_{6}\right] \mathrm{DMSO}$ only one set of relatively sharp signals is observed for the ligand, thus confirming its rather symmetrical structure in solution.

\section{Structure of [ $\left\{\mathrm{Ni}(\mathrm{xbsms}) \mathrm{CuI}_{2}\right]$ (2)}

A projection of the structure of $\left[\left\{\mathrm{Ni}(\mathrm{xbsms}) \mathrm{CuI}_{2}\right]\right.$ is shown in Figure 3. Crystal data are given in the Experimen- 
tal Section and selected bond lengths and angles are given in Table 2. The compound crystallises in the trigonal space group $P 3_{2} 21$. The disordered solvent contained in this crystal structure was modelled as diffuse electron density (see Experimental Section). One tetranuclear complex contains two nickel(II) centres in square-planar surroundings and two copper(I) ions in a tetrahedral geometry. The complex is located on an exact, crystallographic twofold rotation axis and the complex in a single crystal is enantiomerically pure, with clockwise rotation along the positive $c$-axis. Because of the symmetry the compound can be considered as being a dimer of a heterodinuclear nickel-copper complex. The nickel centres have an $\mathrm{S}_{2} \mathrm{~S}_{2}{ }_{2}$ coordination sphere consisting of two thiolate sulfur atoms in enforced cis positions and two thioether sulfur atoms. These nickel ions are in a square-planar geometry with a small tetrahedral distortion defined by a dihedral angle of $5.44(7)^{\circ}$ between the planes $\mathrm{Ni}(1)-\mathrm{S}(6)-\mathrm{S}(9)$ and $\mathrm{Ni}(1)-\mathrm{S}(16)-\mathrm{S}(19)$. The bonds of the thioether sulfur atoms and the thiolate sulfur atoms to $\mathrm{Ni}$ are slightly longer than in the parent nickel complex $[\mathrm{Ni}(\mathrm{xbsms})]^{[26]}$ but are still unexceptional. Both thiolate sulfur atoms of the $\mathrm{NiS}_{4}$ unit are bound as a chelating ligand to a single copper ion with one short $\mathrm{Cu}(2)-\mathrm{S}(6)$ distance of 2.3010(12) $\AA$ and one long $\mathrm{Cu}(2)-\mathrm{S}(16)$ distance of 2.6229(9) $\AA$. The latter thiolate $\mathrm{S}(16)$ is the one that binds to the symmetry-related copper ion $\mathrm{Cu}(2 \mathrm{a})$, with a short copper-thiolate distance of 2.2929(9) $\AA$, and is therefore $\mu_{3}$ bridging between both copper ions and one nickel ion. The copper centres additionally have one coordinated iodide ion and are therefore in a tetrahedral $\mathrm{S}_{3} \mathrm{I}$ coordination environment. The tetranuclear molecules are arranged in a helical motif around a $3_{2}$ screw axis in the crystallographic $c$ direction by $\pi-\pi$ stacking of the xbsms ligands (Figure 4). The geometric centres of the stacking phenyl rings are 3.636(3) $\AA$ apart and the phenyl rings have a dihedral angle of $2.0(3)^{\circ}$. Large, solvent-accessible channels are located along this $3_{2}$ screw axis (see Experimental Section).

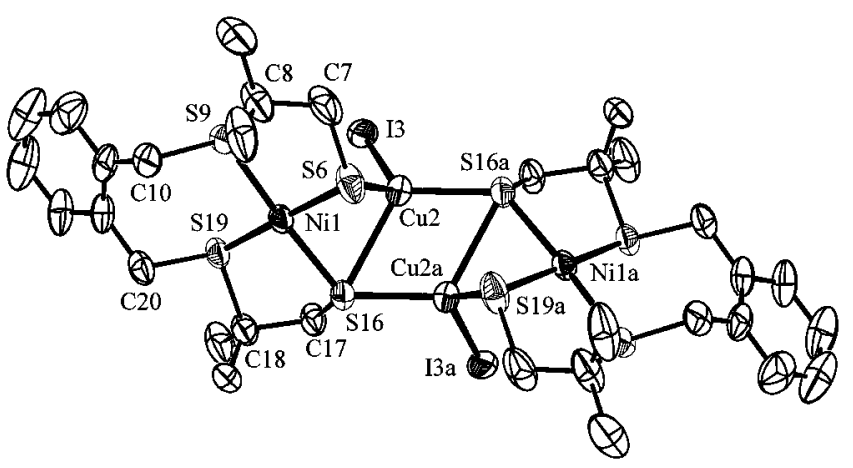

Figure 3. Displacement ellipsoid plot of $\left[\{\mathrm{Ni}(\mathrm{xbsms}) \mathrm{CuI}\}_{2}\right]$ (2), drawn at the $50 \%$ probability level. Hydrogen atoms and solvent molecules have been omitted for clarity.

The NMR spectra of $\mathbf{2}$ were obtained in $\mathrm{CDCl}_{3}$ at room temperature and at $238 \mathrm{~K}$. Due to the presence of the twofold rotation axis, only one set of ligand signals is expected for the tetranuclear complex. The ${ }^{1} \mathrm{H}$ NMR spectrum recorded at room temperature displays signals that are broad-
Table 2. Selected bond lengths $[\AA ̊]$ and angles $\left[{ }^{\circ}\right]$ in $[\mathrm{Ni}(\mathrm{xbsms})-$ $\mathrm{CuI}]_{2}$ (2).

\begin{tabular}{llll}
\hline $\mathrm{Ni}(1) \cdots \mathrm{Cu}(2)$ & $2.7496(6)$ & $\mathrm{Cu}(2) \cdots \mathrm{Cu}(2)^{[\mathrm{a}]}$ & $2.5671(9)$ \\
$\mathrm{Ni}(1)-\mathrm{S}(6)$ & $2.1956(11)$ & $\mathrm{Cu}(2)-\mathrm{S}(6)$ & $2.3010(12)$ \\
$\mathrm{Ni}(1)-\mathrm{S}(9)$ & $2.1936(10)$ & $\mathrm{Cu}(2)-\mathrm{S}(16)$ & $2.6229(9)$ \\
$\mathrm{Ni}(1)-\mathrm{S}(16)$ & $2.1983(10)$ & $\mathrm{Cu}(2)-\mathrm{I}(3)$ & $2.5301(5)$ \\
$\mathrm{Ni}(1)-\mathrm{S}(19)$ & $2.2024(10)$ & $\mathrm{Cu}(2)-\mathrm{S}(16)^{[\mathrm{a}]}$ & $2.2929(9)$ \\
$\mathrm{S}(6)-\mathrm{Ni}(1)-\mathrm{S}(9)$ & $89.94(4)$ & $\mathrm{S}(6)-\mathrm{Cu}(2)-\mathrm{S}(16)$ & $76.12(4)$ \\
$\mathrm{S}(6)-\mathrm{Ni}(1)-\mathrm{S}(16)$ & $87.77(4)$ & $\mathrm{S}(6)-\mathrm{Cu}(2)-\mathrm{I}(3)$ & $122.38(4)$ \\
$\mathrm{S}(6)-\mathrm{Ni}(1)-\mathrm{S}(19)$ & $174.57(4)$ & $\mathrm{S}(6)-\mathrm{Cu}(2)-\mathrm{S}(16)^{[\mathrm{a}]}$ & $114.86(4)$ \\
$\mathrm{S}(9)-\mathrm{Ni}(1)-\mathrm{S}(16)$ & $176.73(4)$ & $\mathrm{S}(16)-\mathrm{Cu}(2)-\mathrm{I}(3)$ & $11.18(3)$ \\
$\mathrm{S}(9)-\mathrm{Ni}(1)-\mathrm{S}(19)$ & $92.35(4)$ & $\mathrm{S}(16)-\mathrm{Cu}(2)-\mathrm{S}(16)^{[\mathrm{a}]}$ & $117.23(3)$ \\
$\mathrm{S}(16)-\mathrm{Ni}(1)-\mathrm{S}(19)$ & $89.73(4)$ & $\mathrm{I}(3)-\mathrm{Cu}(2)-\mathrm{S}(16)^{[\mathrm{a}]}$ & $111.00(3)$
\end{tabular}

[a] Symmetry position: $x-y,-y, 1 / 3-z$.

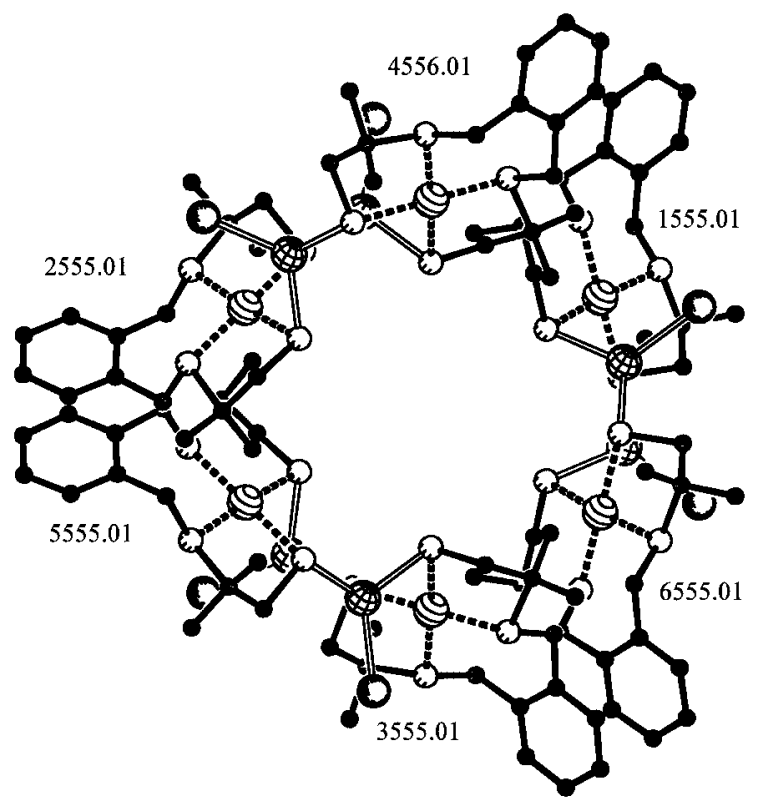

Figure 4. Stacking plot of $\left[\{\mathrm{Ni}(\mathrm{xbsms}) \mathrm{CuI}\}_{2}\right]$ (2), including the ARU numbers. View along the $3_{2}$ screw axis.

ened and only two $\mathrm{CH}_{2}$ resonances can be discerned: one for the ethylene bridges and one for the xylyl- $\mathrm{CH}_{2}$ groups. Furthermore, only one resonance is observed for all four methyl groups. This indicates that both sides of one ligand and both protons on a $\mathrm{CH}_{2}$ group are chemically equivalent in solution on the NMR timescale at room temperature. After cooling the sample to $238 \mathrm{~K}$, the spectrum is sharpened and four doublets are observed for the eight $\mathrm{CH}_{2}$ protons and two singlets are observed for the four methyl groups. In addition, the protons within a $\mathrm{CH}_{2}$ group show COSY and NOESY cross-peaks. This indicates that even at low temperature both sides of one ligand are still chemically equivalent: $\mathrm{C} 7$ and $\mathrm{C} 17, \mathrm{C} 10$ and $\mathrm{C} 20$, and $\mathrm{C} 8$ and $\mathrm{C} 18$ are mutually equivalent. So, in solution the asymmetry of the crystal structure is apparently released. Full assignment of the resonance signals could be made from the COSY and NOESY NMR spectra at $238 \mathrm{~K}$. The signal of one of the benzylic protons has shifted $1.8 \mathrm{ppm}$ downfield to $\delta=$ $5.6 \mathrm{ppm}$ as compared to that in the parent nickel complex. This rather large shift is comparable to the shift of the signal of one benzylic proton in $\left[\mathrm{Ni}(\mathrm{xbsms}) \mathrm{Fe}(\mathrm{CO})_{4}\right] .^{[28]} \mathrm{From}$ 
the crystal structure, however, no apparent interactions can be discerned that may be responsible for this downfield shift; the shortest $\mathrm{Ni}$-..benzylic-H distance is $3.27 \AA$, and an iodine- $\mathrm{H}$ interaction of $3.1 \AA$ is present.

\section{Structure of $\left[\mathrm{Ni}_{2}\right.$ (bsms) $\left.{ }_{3} \mathrm{ZnBr}_{3}\right]$ (3)}

A projection of the structure of $\left[\mathrm{Ni}_{2}(\mathrm{bsms})_{3} \mathrm{ZnBr}_{3}\right]$ is shown in Figure 5. Crystal data are given in the Experimental Section and selected bond lengths and angles in Table 3. The asymmetric unit contains the trinuclear complex $\left[\mathrm{Ni}_{2}(\mathrm{bsms})_{3} \mathrm{ZnBr}_{3}\right]$ and two molecules of acetone. The trinuclear complex is built up from two nickel(II) centres with square-planar surroundings and a tetrahedral zinc(II) ion. $\mathrm{Ni}(1)$ has an $\mathrm{S}_{2} \mathrm{~S}_{2}{ }_{2}$ coordination environment originating from two bsms ligands, with the two thiolate sulfur atoms in cis positions. The square-planar coordination of this nickel ion has a small tetrahedral distortion, with an interplanar angle of $4.7(3)^{\circ}$. Both thiolate sulfur atoms are bridging to the second nickel ion, $\mathrm{Ni}(2)$, which is in an $\mathrm{S}_{3} \mathrm{~S}^{\prime}$ coordination environment consisting of the already mentioned bridging thiolate sulfur atoms and an additional didentate bsms ligand. The $\mathrm{Ni}(2)$ ion is also in a rather perfect square-planar geometry with a small tetrahedral distortion

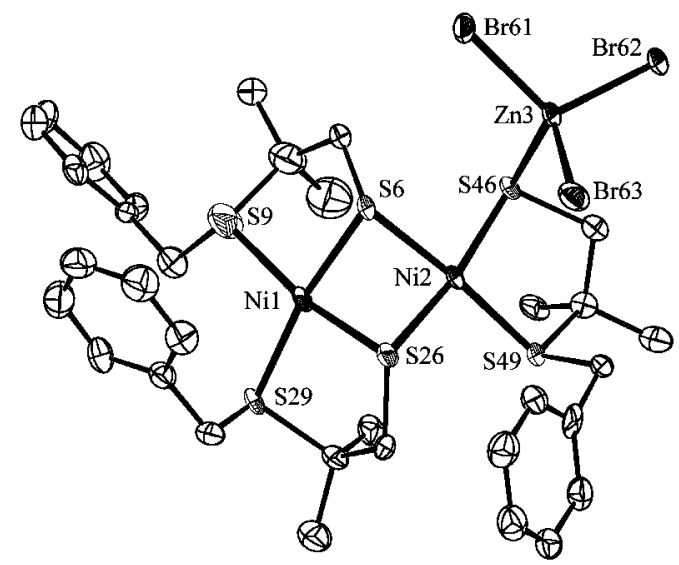

Figure 5. Displacement ellipsoid plot of $\left[\mathrm{Ni}_{2}(\mathrm{bsms})_{3} \mathrm{ZnBr}_{3}\right]$ (3), drawn at the $50 \%$ probability level. Hydrogen atoms and solvent molecules are omitted for clarity.

Table 3. Selected bond lengths $[\AA]$ and angles $\left[{ }^{\circ}\right]$ in $\left[\mathrm{Ni}_{2}(\mathrm{bsms})_{3^{-}}\right.$ $\left.\mathrm{ZnBr}_{3}\right]$ (3).

\begin{tabular}{llll}
\hline $\mathrm{Ni}(1) \cdots \mathrm{Ni}(2)$ & $2.864(3)$ & $\mathrm{Ni}(2) \cdots \mathrm{Zn}(3)$ & $3.616(3)$ \\
$\mathrm{Ni}(1)-\mathrm{S}(6)$ & $2.162(4)$ & $\mathrm{Zn}(3)-\mathrm{S}(46)$ & $2.414(4)$ \\
$\mathrm{Ni}(1)-\mathrm{S}(9)$ & $2.211(5)$ & $\mathrm{Zn}(3)-\mathrm{Br}(61)$ & $2.379(2)$ \\
$\mathrm{Ni}(1)-\mathrm{S}(26)$ & $2.147(4)$ & $\mathrm{Zn}(3)-\mathrm{Br}(62)$ & $2.406(2)$ \\
$\mathrm{Ni}(1)-\mathrm{S}(29)$ & $2.192(4)$ & $\mathrm{Zn}(3)-\mathrm{Br}(63)$ & $2.402(2)$ \\
$\mathrm{Ni}(2)-\mathrm{S}(6)$ & $2.211(4)$ & $\mathrm{Ni}(2)-\mathrm{S}(46)$ & $2.175(4)$ \\
$\mathrm{Ni}(2)-\mathrm{S}(26)$ & $2.212(4)$ & $\mathrm{Ni}(2)-\mathrm{S}(49)$ & $2.192(4)$ \\
$\mathrm{S}(6)-\mathrm{Ni}(1)-\mathrm{S}(9)$ & $87.27(17)$ & $\mathrm{S}(26)-\mathrm{Ni}(2)-\mathrm{S}(46)$ & $170.85(16)$ \\
$\mathrm{S}(6)-\mathrm{Ni}(1)-\mathrm{S}(26)$ & $80.93(15)$ & $\mathrm{S}(26)-\mathrm{Ni}(2)-\mathrm{S}(49)$ & $97.36(16)$ \\
$\mathrm{S}(6)-\mathrm{Ni}(1)-\mathrm{S}(29)$ & $170.60(17)$ & $\mathrm{S}(46)-\mathrm{Ni}(2)-\mathrm{S}(49)$ & $91.77(15)$ \\
$\mathrm{S}(9)-\mathrm{Ni}(1)-\mathrm{S}(26)$ & $168.03(18)$ & $\mathrm{S}(46)-\mathrm{Zn}(3)-\mathrm{Br}(61)$ & $111.74(11)$ \\
$\mathrm{S}(9)-\mathrm{Ni}(1)-\mathrm{S}(29)$ & $101.04(17)$ & $\mathrm{S}(46)-\mathrm{Zn}(3)-\mathrm{Br}(62)$ & $100.99(11)$ \\
$\mathrm{S}(26)-\mathrm{Ni}(1)-\mathrm{S}(29)$ & $90.88(15)$ & $\mathrm{S}(46)-\mathrm{Zn}(3)-\mathrm{Br}(63)$ & $106.19(12)$ \\
$\mathrm{S}(6)-\mathrm{Ni}(2)-\mathrm{S}(26)$ & $78.45(15)$ & $\mathrm{Br}(61)-\mathrm{Zn}(3)-\mathrm{Br}(62)$ & $112.93(9)$ \\
$\mathrm{S}(6)-\mathrm{Ni}(2)-\mathrm{S}(46)$ & $92.46(16)$ & $\mathrm{Br}(61)-\mathrm{Zn}(3)-\mathrm{Br}(63)$ & $109.66(9)$ \\
$\mathrm{S}(6)-\mathrm{Ni}(2)-\mathrm{S}(49)$ & $175.01(15)$ & $\mathrm{Br}(62)-\mathrm{Zn}(3)-\mathrm{Br}(63)$ & $114.86(8)$ \\
\hline
\end{tabular}

and a dihedral angle of only $2.9(2)^{\circ}$. The thiolate sulfur atom of this third bsms ligand is bridging between $\mathrm{Ni}(2)$ and the zinc(II) ion, which has an $\mathrm{SBr}_{3}$ coordination environment. The bond lengths to nickel are similar to those in the parent nickel complex $\left[\mathrm{Ni}(\mathrm{bsms})_{2}\right]$ and are unexceptional. ${ }^{[26]}$

The NMR spectroscopic results confirm the diamagnetic properties of the complex, with two square-planar low-spin nickel(II) centres and a zinc(II) ion, which is retained in solution. Quite unexpectedly, only a single set of resonances is discernible for the three ligands, which makes the spectrum quite similar to the ${ }^{1} \mathrm{H}$ NMR spectrum of $\left[\mathrm{Ni}(\mathrm{bsms})_{2}\right]$.

\section{Structure of $\left[\mathrm{Ni}_{3}(\mathrm{xbsms})_{2}\left(\mathrm{ZnBr}_{3}\right)_{2}\right]$ (4)}

A structure proposal based on elemental analysis and IR, NMR and ligand-field spectroscopy is shown in Figure 6. The structure proposal is based on the known type of trinuclear complexes of the form $\left[\mathrm{Ni}_{3}(\mathrm{xbsms})_{2}\right]^{2+}$, which are composed of a zig-zag chain of three square planes similar to that reported for $\left[\mathrm{Ni}_{3}(\mathrm{bsms})_{4}\right]^{2+} \cdot{ }^{[15]}$ This arrangement leaves space for two $\mathrm{ZnBr}_{3}$ units to coordinate above and below the trinuclear complex, similar to the binding observed in $\left[\mathrm{Ni}_{2}(\mathrm{bsms})_{3} \mathrm{ZnBr}_{3}\right]$. The ${ }^{1} \mathrm{H} \mathrm{NMR}$ spectrum of this compound again shows only one set of sharp signals, in agreement with a symmetrical structure and square-planar surrounding for the nickel(II) ions. The coordination of the $\mathrm{ZnBr}_{3}$ groups apparently has a stabilizing effect on the fluxionality of the nickel ions as no sharp NMR spectrum could be obtained for the parent trinuclear complex, even at low temperature. ${ }^{[27]}$

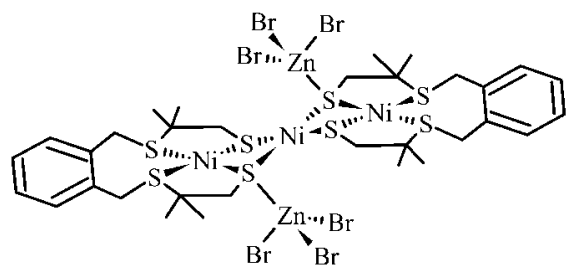

Figure 6. Proposed structure of $\left[\mathrm{Ni}_{3}(\mathrm{xbsms})_{2}\left(\mathrm{ZnBr}_{3}\right)_{2}\right]$ (4).

\section{UV/Vis/NIR Spectroscopy of the Complexes}

The square-planar surrounding of the nickel(II) ions in all of the mixed-metal complexes discussed above is reflected in their ligand-field spectra. The UV/Vis/NIR data are presented in Table 4. The nickel-copper complexes are black solids that yield brown solutions both in chloroform and in acetonitrile. These complexes show a very broad absorption band in the solid state with the diffuse reflectance technique. The nickel-zinc complexes are brown solids that also yield brown solutions in both chloroform and acetonitrile. $\left[\mathrm{Ni}_{3}(\mathrm{xbsms})_{2}\left(\mathrm{ZnBr}_{3}\right)_{2}\right]$ (4) dissolves very poorly in chloroform and therefore the ligand-field data of this complex are only given for acetonitrile. For $\left[\mathrm{Ni}_{2}(\mathrm{bsms})_{3} \mathrm{ZnBr}_{3}\right]$ (3), the differences in the ligand-field spectra of a solution in chloroform and a solution in acetonitrile are very small, 
Table 4. Electronic absorption maxima for the $\mathrm{NiCu}$ and $\mathrm{NiZn}$ complexes.

\begin{tabular}{|c|c|c|c|}
\hline & $\tilde{v}\left[10^{3} \mathrm{~cm}^{-1}\right]($ & & \\
\hline & Solid state ${ }^{[a]}$ & Chloroform & Acetonitrile \\
\hline$\left[\left\{\mathrm{Ni}(\mathrm{bsms})_{2}\right\}_{3}(\mathrm{CuI})_{5}\right](\mathbf{1})$ & 21.2 & $22.6\left(14 \times 10^{3}\right)$ & \\
\hline & & $28.0\left(14 \times 10^{3}\right)$ & $26.2(\mathrm{sh})$ \\
\hline & & & $34.4(\mathrm{sh})$ \\
\hline & & $38.1\left(62 \times 10^{3}\right)$ & $40.3\left(107 \times 10^{3}\right)$ \\
\hline & & & $47.6\left(255 \times 10^{3}\right)$ \\
\hline$\left[\{\mathrm{Ni}(\mathrm{xbsms}) \mathrm{CuI}\}_{2}\right](2)$ & & $14.5(\mathrm{sh})$ & $14.5(300)$ \\
\hline & 21.0 & $20.6(2400)$ & $21.8(630)$ \\
\hline & & $26.2(3100)$ & $30.0(\mathrm{sh})$ \\
\hline & & $35.6\left(14 \times 10^{3}\right)$ & $35.1\left(13 \times 10^{3}\right)$ \\
\hline & & & $40.3\left(20 \times 10^{3}\right)$ \\
\hline$\left[\mathrm{Ni}_{2}(\mathrm{bsms})_{3} \mathrm{ZnBr}_{3}\right]$ (3) & 15.1 & & $13.6(120)$ \\
\hline & 20.2 & $19.3(\mathrm{sh})$ & $20.4(\mathrm{sh})$ \\
\hline & 24.1 & $25.0(2200)$ & $25.8(4500)$ \\
\hline & & $34.4(\mathrm{sh})$ & $34.4(\mathrm{sh})$ \\
\hline & & $36.7\left(12 \times 10^{3}\right)$ & $37.2\left(21 \times 10^{3}\right)$ \\
\hline$\left[\mathrm{Ni}_{3}(\mathrm{xbsms})_{2}\left(\mathrm{ZnBr}_{3}\right)_{2}\right](4)$ & 19.5 & & $19.7(6600)$ \\
\hline & 23.2 & & $23.4\left(19 \times 10^{3}\right)$ \\
\hline & 30.2 & & \\
\hline & 37.5 & & $36.2\left(54 \times 10^{3}\right)$ \\
\hline
\end{tabular}

[a] Diffuse reflectance.

thus indicating that solvent coordination does not take place in this case. Coordination of acetonitrile cannot be excluded for the nickel-copper complexes [ $\{\mathrm{Ni}(\mathrm{xbsms})-$ $\left.\mathrm{CuI}\}_{2}\right]$ and $\left[\left\{\mathrm{Ni}(\mathrm{bsms})_{2}\right\}_{3}(\mathrm{CuI})_{5}\right]$. The d-d transitions of the nickel centres in all complexes are at slightly lower energy and the ligand-to-metal charge-transfer transitions are at higher energy compared with the starting complexes $\left[\mathrm{Ni}(\mathrm{bsms})_{2}\right]$ and $[\mathrm{Ni}(\mathrm{xbsms})]$ (see Table 4). ${ }^{[26]}$ These changes are just the opposite to the shifts in energy in ligand field for the $\left[\left\{\mathrm{NiLFeX}_{2}\right\}_{2}\right]$ complexes $\left[\left\{\mathrm{Ni}(\mathrm{xbsms}) \mathrm{FeCl}_{2}\right\}_{2}\right]$, $\left[\left\{\mathrm{Ni}(\mathrm{xbsms}) \mathrm{FeBr}_{2}\right\}_{2}\right]$ and $\left[\left\{\mathrm{Ni}(\mathrm{xbsms}) \mathrm{FeI}_{2}\right\}_{2}\right]^{[28]}$ Apparently, the somewhat softer $\mathrm{CuI}$ and $\mathrm{ZnBr}_{3}$ units accept more electron density from the thiolate sulfur atoms.

\section{Discussion}

The ability of $\left[\mathrm{NiN}_{2} \mathrm{~S}_{2}\right]$ complexes to act as a ligand to other metal ions has long been recognized, but intense efforts to study the binding of mononuclear $\left[\mathrm{NiN}_{2} \mathrm{~S}_{2}\right]$ to transition metal ions were triggered by the publication of the $\mathrm{X}$-ray structure of ACS. Many examples of the versatile binding of nickel dithiolate complexes - as compared with "normal" didentate sulfur ligands - have now been reported. As the reactivity of the mononuclear $\mathrm{NiS}_{4}$ complexes $[\mathrm{Ni}(\mathrm{xbsms})]$ and $\left[\mathrm{Ni}(\mathrm{bsms})_{2}\right.$ ] towards iron sources is rather similar to that of $\mathrm{NiN}_{2} \mathrm{~S}_{2}$ complexes, the unique products formed with copper and zinc salts were quite unexpected. Regarding the $\mathrm{NiS}_{4}$ complexes as dithiolate ligands makes the novel octanuclear compound [ $\{\mathrm{Ni}-$ (bsms $\left.\left.)_{2}\right\}_{3}(\mathrm{CuI})_{5}\right]$ a $\left[\mathrm{Cu}_{5}\left(" \mathrm{SS}_{2} \text { ") }\right)_{3}\right]$ cluster. Numerous $\mathrm{Cu}^{\mathrm{I}}$ thiolate clusters have been reported; however, only two clusters have been reported with a related $\mathrm{Cu}_{5}(\mathrm{SR})_{6}$ arrangement. ${ }^{[29]}$ The copper centres in these complexes are also in a trigonal-bipyramidal array, each axial-equatorial edge of which is bridged by a thiolate sulfur atom. However, the copper ions do not have additional halogen ions coordinated and the $\mathrm{Cu} \cdots \mathrm{Cu}$ distances are much smaller and are more likely to indicate a metal-metal interaction.

The rearrangement of the didentate ligands in $\left[\left\{\mathrm{Ni}(\mathrm{bsms})_{2}\right\}_{3}(\mathrm{CuI})_{5}\right]$ to form cis-planar nickel complexes would imply that a similar structure could possibly be obtained from $[\mathrm{Ni}(\mathrm{xbsms})]$. However, the resulting complex $\left[\left\{\mathrm{Ni}(\mathrm{xbsms}) \mathrm{CuI}_{2}\right]\right.$ is obviously different and, as similar reaction conditions were applied in the two syntheses, the resulting dissimilar structures must be a consequence of packing effects. The reported ${ }^{[6,16]}$ complex $\left[\left\{\mathrm{Ni}\left(\mathrm{N}_{2} \mathrm{~S}_{2}\right)\right\}_{3}(\mathrm{CuBr})_{2}\right]$ may be regarded as being derived from the present $\mathrm{Ni}_{3} \mathrm{Cu}_{5}$ complex by removal of the three equatorial $\mathrm{CuI}$ units. Structures have been reported of $\left[\left\{\mathrm{Ni}\left(\mathrm{N}_{2} \mathrm{~S}_{2}\right)\right\}_{2} \mathrm{Cu}_{2}\right]^{2+}$, which have the same nickel/copper ratio as $\left[\{\mathrm{Ni}(\mathrm{xbsms}) \mathrm{CuI}\}_{2}\right]$ but which do not contain coordinated halides and in which the sulfur binding is different. ${ }^{[5,7]}$

The reaction of $\mathrm{NiN}_{2} \mathrm{~S}_{2}$ complexes with copper and zinc halides has been shown to result in similar structures in some cases ${ }^{[12]}$ although different topologies have also been reported. ${ }^{[7]}$ Our new nickel-zinc complexes $\left[\mathrm{Ni}_{2}(\mathrm{bsms})_{3}\right.$ $\left.\mathrm{ZnBr}_{3}\right]$ and $\left[\mathrm{Ni}_{3}(\mathrm{xbsms})_{2}\left(\mathrm{ZnBr}_{3}\right)_{2}\right]$ are noticeably different from these earlier reported structures, and are also quite different from each other, as a result of dissociation of the didentate bsms ligand from part of the mononuclear complex and re-assembly to form a dinuclear core similar to that of the nickel ethanedithiolate compound $\left[\mathrm{Ni}_{2}(\mathrm{edt})_{3}\right]^{[30]}$ The binding of the $\mathrm{ZnBr}_{3}{ }^{-}$group to one thiolate sulfur atom is similar to the binding observed in the dinuclear complex $\left[\mathrm{Ni}\left(\mathrm{N}_{2} \mathrm{~S}_{2}\right) \mathrm{ZnCl}_{2}(\mathrm{dmf})\right]{ }^{[7]}$ The proposed structure of the pentanuclear complex of general formula $\left[\mathrm{Ni}_{3}(\mathrm{xbsms})_{2}\left(\mathrm{ZnBr}_{3}\right)_{2}\right]$ is based on the assumption of a similar binding of the $\mathrm{ZnBr}_{3}{ }^{-}$groups; binding at two sides of the trinuclear core is proposed for reasons of steric bulk and the existence of a symmetrical structure as indicated by NMR spectroscopy. 
The structures of the products of the reactions of the mononuclear complexes $[\mathrm{Ni}(\mathrm{xbsms})]$ and $\left[\mathrm{Ni}(\mathrm{bsms})_{2}\right]$ with copper and zinc salts are remarkably different from those that have been reported earlier, and the reactivity of these products as well as that of the trinuclear nickel complexes also differ from the analogous $\mathrm{NiN}_{2} \mathrm{~S}_{2}$ compounds. A study ${ }^{[6]}$ of the reactivity of the complexes $\left[\left\{\mathrm{Ni}\left(\mathrm{N}_{2} \mathrm{~S}_{2}\right)\right\}_{3}\right.$ $\left.(\mathrm{ZnCl})_{2}\right]^{2+}, \quad\left[\left\{\mathrm{Ni}\left(\mathrm{N}_{2} \mathrm{~S}_{2}\right)\right\}_{3}(\mathrm{CuBr})_{2}\right]$ and $\left[\left\{\mathrm{Ni}\left(\mathrm{N}_{2} \mathrm{~S}_{2}\right)\right\}_{2} \mathrm{Ni}\right]^{2+}$ towards nickel, copper and zinc salts resulted in a qualitative ranking of metal ion affinity by the nickel dithiolate ligand, i.e. $\mathrm{Zn}^{2+}<\mathrm{Ni}^{2+}<\mathrm{Cu}^{+}$. With this in mind the nickel-zinc complexes $\left[\mathrm{Ni}_{2}(\mathrm{bsms})_{3} \mathrm{ZnBr}_{3}\right]$ and $\left[\mathrm{Ni}_{3}(\mathrm{xbsms})_{2}-\right.$ $\left.\left(\mathrm{ZnBr}_{3}\right)_{2}\right]$ have been tested for their reactivity towards $\mathrm{Ni}\left(\mathrm{BF}_{4}\right)_{2}$ and $\mathrm{CuI}$. Both complexes show no reactivity towards $\mathrm{Ni}\left(\mathrm{BF}_{4}\right)_{2}$ and only the starting complexes were recovered after $24 \mathrm{~h}$. The complex $\left[\mathrm{Ni}_{2}(\mathrm{bsms})_{2} \mathrm{ZnBr}_{3}\right]$, however, does show reactivity towards $\mathrm{CuI}$; this reaction again gives the stable octanuclear cluster $\left[\left\{\mathrm{Ni}(\mathrm{bsms})_{2}\right\}_{3^{-}}\right.$ $\left.(\mathrm{CuI})_{5}\right]$. The complex $\left[\mathrm{Ni}_{3}(\mathrm{xbsms})_{2}\left(\mathrm{ZnBr}_{3}\right)_{2}\right]$ does not show reactivity towards $\mathrm{CuI}$, which may be related to the low solubility of this complex. The trinuclear nickel complexes appear to be comparatively inert, and from most of the reactions only the starting materials could be recovered.

\section{Conclusions}

Four new heteronuclear aggregates of various composition have been synthesised and characterised by using the $\mathrm{NiS}_{4}$ compounds [Ni(xbsms)] and $\left[\mathrm{Ni}(\mathrm{bsms})_{2}\right]$ as a ligand for copper and zinc salts. Despite the similar reactivity of these two complexes towards iron salts, the products of the reactions with $\mathrm{CuI}$ and $\mathrm{ZnBr}_{2}$ are diverse. The novel octanuclear structure of $\left[\left\{\mathrm{Ni}(\mathrm{bsms})_{2}\right\}_{3}(\mathrm{CuI})_{5}\right]$ shows a unique arrangement of copper and nickel centres, with a central trigonal-bipyramidal array of copper ions to which the three $\mathrm{NiS}_{2} \mathrm{~S}_{2}^{\prime}$ units act as capping ligands. This remarkable complex represents another important example of the structural versatility possible for the reaction products of nickel dithiolate complexes as ligands to other transition metal ions. The tetranuclear structure $\left[\{\mathrm{Ni}(\mathrm{xbsms}) \mathrm{CuI}\}_{2}\right]$ shows unprecedented asymmetric bridging of the thiolate sulfur atoms, with one of the thiolate groups binding to one copper ion and the other one $\mu_{3}$-bridging to two copper ions. The trinuclear complex $\left[\mathrm{Ni}_{2}(\mathrm{bsms})_{3} \mathrm{ZnBr}_{3}\right]$ is formed as a result of dissociation of the didentate bsms ligand from part of the mononuclear complex and reassembly to form the dinuclear core. The trans binding of the didentate ligand in the starting complex $\left[\mathrm{Ni}(\mathrm{bsms})_{2}\right]$ appears not to limit its ability to bind to other transition metal ions as a chelating ligand; it does, however, result in the formation of new, unexpected aggregates. The formation of these cluster compounds as opposed to the desired dinuclear complexes emphasises the importance of the site isolation in metalloenzymes and the difficulty of controlling the product formation in vitro.

\section{Experimental Section}

Chemicals: All preparations were carried out in reagent-grade solvents. All chemicals used in the syntheses were obtained from
Acros or Aldrich and were used without further purification. The complexes were synthesised under argon using standard Schlenk techniques. Solvents were deoxygenated and dried with molecular sieves. The synthesis of $\left[\mathrm{Ni}(\mathrm{bsms})_{2}\right]$ and $[\mathrm{Ni}(\mathrm{xbsms})]$ has been reported earlier. ${ }^{[26]}$

Physical Measurements: IR spectra were recorded with a PerkinElmer FT-IR Paragon 1000 spectrophotometer equipped with a golden-gate ATR device, using the reflectance technique (4000$300 \mathrm{~cm}^{-1}$; resolution $4 \mathrm{~cm}^{-1}$ ). Elemental analyses were carried out with a Perkin-Elmer series II CHNS/O analyzer 2400. Metal analyses were performed with a Perkin-Elmer 3100 atomic absorption (AAS) and flame emission spectrometer using a linear calibration method. Due to the presence of variable amounts of solvent encapsulated in the complexes, some of the analytical data may be considered not satisfactory. Ligand-field spectra were obtained with a Perkin-Elmer Lambda 900 spectrophotometer. The diffuse reflectance technique, with $\mathrm{MgO}$ as a reference, was used for the solid compounds. Ligand-field spectra of the solutions were obtained with the solvent in the reference beam. NMR spectra were recorded with a Bruker WM $300 \mathrm{MHz}$ spectrometer or a Jeol FX-200 Teqmac. ${ }^{1} \mathrm{H}$ and ${ }^{13} \mathrm{C}$ chemical shifts are quoted in ppm relative to tetramethylsilane (TMS)

[\{Ni(bsms $\left.\left.)_{2}\right\}_{3}(\mathrm{CuI})_{5}\right]$ (1): A solution of $\mathrm{CuI}(0.072 \mathrm{~g}, 0.38 \mathrm{mmol})$ in $80 \mathrm{~mL}$ of $\mathrm{CH}_{3} \mathrm{CN}$ was added to a solution of [Ni(bsms $\left.)_{2}\right](0.18 \mathrm{~g}$, $0.37 \mathrm{mmol}$ ) in $170 \mathrm{~mL}$ of $\mathrm{CH}_{3} \mathrm{CN}$, and the solution was stirred for $20 \mathrm{~h}$. The solvent was then evaporated and the crude product was recrystallised from acetone/diethyl ether. Dark-red crystals suitable for X-ray diffraction were formed in a yield of $0.146 \mathrm{~g}(75 \%)$. IR: $\tilde{v}_{\max }=2960 \mathrm{~m}, 2907 \mathrm{~m}, 1495 \mathrm{~m}, 1454 \mathrm{~m}, 1386 \mathrm{~m}, 1368 \mathrm{~m}, 1256 \mathrm{w}$, $1228 \mathrm{w}, 1199 \mathrm{w}, 1139 \mathrm{~m}, 1083 \mathrm{~m}, 1071 \mathrm{~m}, 1028 \mathrm{w}, 955 \mathrm{w}, 925 \mathrm{w}$, $889 \mathrm{w}, 772 \mathrm{~m}, 696 \mathrm{vs}, 668 \mathrm{~m}, 476 \mathrm{~m} \mathrm{~cm}^{-1}$. ${ }^{1} \mathrm{H}$ NMR $(300.13 \mathrm{MHz}$, [D 6 dmso, $298 \mathrm{~K}): \delta=7.31(\mathrm{~m}, 30 \mathrm{H}, \mathrm{Ph}), 3.68\left(\mathrm{~s}, 12 \mathrm{H}, \mathrm{Ph}-\mathrm{CH}_{2}-\right.$ $\mathrm{S}), 2.26\left[\mathrm{~s}, 12 \mathrm{H}, \mathrm{C}\left(\mathrm{CH}_{3}\right)_{2}-\mathrm{CH}_{2}-\mathrm{S}\right], 1.21\left(\mathrm{~s}, 36 \mathrm{H}, \mathrm{CH}_{3}\right) \mathrm{ppm}$. $\mathrm{C}_{66} \mathrm{H}_{90} \mathrm{Cu}_{5} \mathrm{I}_{5} \mathrm{Ni}_{3} \mathrm{~S}_{12}$ (2396.5): calcd. C 33.08, H 3.79, Cu 13.26, Ni 7.35, S 16.05; found C 33.25, H 4.17, Cu 13.05, Ni 7.71, S 15.44.

[\{Ni(xbsms)CuI $\left.\}_{2}\right]$ (2): $\mathrm{CuI}(0.19 \mathrm{~g}, 1.0 \mathrm{mmol})$ in $80 \mathrm{~mL}$ of $\mathrm{CH}_{3} \mathrm{CN}$ was slowly added to a solution of $[\mathrm{Ni}(\mathrm{xbsms})](0.4 \mathrm{~g}, 1.0 \mathrm{mmol})$ in $100 \mathrm{~mL}$ of $\mathrm{CH}_{3} \mathrm{CN}$, and the solution was stirred for $23 \mathrm{~h}$. After evaporation of the solvent, the product was recrystallised from dmf/ diethyl ether in a yield of $0.46 \mathrm{~g}(78 \%)$. Dark-red crystals suitable for X-ray diffraction were obtained. IR: $\tilde{v}_{\max }=2963 \mathrm{~m}, 2926 \mathrm{~m}$, $1676 \mathrm{~m}, 1660$ vs, $1497 \mathrm{~m}, 1454 \mathrm{~m}, 1437 \mathrm{~m}, 1382 \mathrm{~m}, 1362 \mathrm{~m}, 1253 \mathrm{~m}$, 1227 m, 1190 w, 1134 m, 1079 s, 956 m, 890 m, 768 s, 759 m, 743 w, $691 \mathrm{~s}, 668 \mathrm{~s}, 660 \mathrm{~m}, 606 \mathrm{~m}, 579 \mathrm{w}, 488 \mathrm{~m}, 462 \mathrm{~m} \mathrm{~cm}^{-1} .{ }^{1} \mathrm{H}$ NMR $\left(300.13 \mathrm{MHz}, \mathrm{CDCl}_{3}, 238 \mathrm{~K}\right): \delta=7.28\left(\mathrm{~m}, 4 \mathrm{H}, \mathrm{C}^{23}-H, \mathrm{C}^{26}-H\right)$, $7.18\left(\mathrm{~m}, 4 \mathrm{H}, \mathrm{C}^{24}-H, \mathrm{C}^{25}-H\right), 5.65\left(\mathrm{~d},{ }^{2} J=12.4 \mathrm{~Hz}, 4 \mathrm{H}, \mathrm{C}^{10 / 20} H \mathrm{H}\right)$, $3.55\left(\mathrm{~d},{ }^{2} J=12.4 \mathrm{~Hz}, 4 \mathrm{H}, \mathrm{C}^{10 / 20} \mathrm{H} H\right), 2.84\left(\mathrm{~d},{ }^{2} J=12.9 \mathrm{~Hz}, 4 \mathrm{H}\right.$, $\left.\mathrm{C}^{7 / 17} \mathrm{HH}\right), 2.45\left(\mathrm{~d},{ }^{2} \mathrm{~J}=12.9 \mathrm{~Hz}, 4 \mathrm{H}, \mathrm{C}^{7 / 17} \mathrm{HH}\right), 1.74(\mathrm{~s}, 12 \mathrm{H}$, $\left.\mathrm{CH}_{3}\right), 1.48\left(\mathrm{~s}, 12 \mathrm{H}, \mathrm{CH}_{3}^{\prime}\right) \mathrm{ppm}$; see Figure 3 for numbering scheme. $\mathrm{C}_{32} \mathrm{H}_{48} \mathrm{Cu}_{2} \mathrm{I}_{2} \mathrm{Ni}_{2} \mathrm{~S}_{8}$ (1187.5): calcd. C 32.37, $\mathrm{H} 4.07, \mathrm{Cu}$ 10.70, Ni 9.89, S 21.60; found C 33.24, H 4.45, Cu 10.55, Ni 9.86, S 18.94 .

[ $\mathbf{N i}_{\mathbf{2}}$ (bsms) $\mathbf{Z n n B r}_{3}$ ] (3): $\mathrm{ZnBr}_{2}(0.23 \mathrm{~g}, 1.0 \mathrm{mmol})$ in $50 \mathrm{~mL}$ of $\mathrm{CH}_{3} \mathrm{CN}$ was added to a solution of $\left[\mathrm{Ni}(\mathrm{bsms})_{2}\right](0.50 \mathrm{~g}, 1.04 \mathrm{mmol})$ in $200 \mathrm{~mL}$ of $\mathrm{CH}_{3} \mathrm{CN}$. The solution changed colour from light brown to dark brown and was stirred for $19 \mathrm{~h}$. The solvent was evaporated and the obtained product was recrystallised from acetone/hexane. A yield of $0.48 \mathrm{~g}$ of red crystals suitable for X-ray diffraction was obtained (80\%). IR: $\tilde{v}_{\max }=2957 \mathrm{w}, 2920 \mathrm{w}, 1601 \mathrm{w}$, $1495 \mathrm{~m}, 1463 \mathrm{~m}, 1455 \mathrm{~m}, 1417 \mathrm{~m}, 1385 \mathrm{w}, 1362 \mathrm{~m}, 1264 \mathrm{~m}, 1240 \mathrm{~m}$, $1221 \mathrm{~m}, 1195 \mathrm{~m}, 1141 \mathrm{~m}, 1082 \mathrm{~m}, 1070 \mathrm{~m}, 1030 \mathrm{w}, 953 \mathrm{~m}, 879 \mathrm{w}$, $806 \mathrm{~m}, 767 \mathrm{~s}, 736 \mathrm{w}, 699 \mathrm{vs}, 668 \mathrm{w}, 620 \mathrm{w}, 585 \mathrm{w}, 528 \mathrm{~m}, 487 \mathrm{~s}$, 
Table 5. Crystal and structure-refinement data for $\left[\left\{\mathrm{Ni}(\mathrm{bsms})_{2}\right\}_{3}(\mathrm{CuI})_{5}\right](\mathbf{1}),\left[\{\mathrm{Ni}(\mathrm{xbsms}) \mathrm{CuI}\}_{2}\right](\mathbf{2})$ and $\left[\mathrm{Ni}_{2}(\mathrm{bsms})_{3} \mathrm{ZnBr}_{3}\right](\mathbf{3})$.

\begin{tabular}{|c|c|c|c|}
\hline Complex & 1 & 2 & 3 \\
\hline Empirical formula & $\begin{array}{l}\mathrm{C}_{66} \mathrm{H}_{90} \mathrm{Cu}_{5} \mathrm{I}_{5} \mathrm{Ni}_{3} \mathrm{~S}_{12}\left(\mathrm{C}_{3} \mathrm{H}_{6} \mathrm{O}\right)_{2} \\
\left(\mathrm{C}_{4} \mathrm{H}_{10} \mathrm{O}\right)_{0.9}\end{array}$ & $\begin{array}{l}\mathrm{C}_{32} \mathrm{H}_{48} \mathrm{Cu}_{2} \mathrm{I}_{2} \mathrm{Ni}_{2} \mathrm{~S}_{8}+\text { disordered sol- } \\
\text { vent }\end{array}$ & $\begin{array}{l}\mathrm{C}_{33} \mathrm{H}_{45} \mathrm{Br}_{3} \mathrm{Ni}_{2} \mathrm{~S}_{6} \mathrm{Zn} \\
\left(\mathrm{C}_{3} \mathrm{H}_{6} \mathrm{O}\right)_{2}\end{array}$ \\
\hline Formula mass & 2579.41 & $1187.48^{\mathrm{a}}$ & 1172.73 \\
\hline Crystal colour & dark red & dark red & red \\
\hline Crystal dimensions $[\mathrm{mm}]$ & $0.42 \times 0.27 \times 0.09$ & $0.15 \times 0.15 \times 0.42$ & $0.03 \times 0.42 \times 0.48$ \\
\hline Crystal system & triclinic & trigonal & triclinic \\
\hline Space group & $P \overline{1}$ (no. 2) & $P 3_{2} 21$ (no. 154 ) & $P \overline{1}$ (no. 2) \\
\hline$a[\AA]$ & $14.5217(19)$ & $13.0141(1)$ & $10.249(3)$ \\
\hline$b[\AA]$ & $14.5596(6)$ & 13.0141(1) & $11.549(3)$ \\
\hline$c[\AA]$ & $46.735(4)$ & $26.9539(2)$ & $21.388(7)$ \\
\hline$\alpha\left[^{\circ}\right]$ & $98.451(7)$ & 90 & $104.28(3)$ \\
\hline$\beta\left[^{\circ}\right]$ & $97.003(9)$ & 90 & $96.52(2)$ \\
\hline$\gamma\left[{ }^{\circ}\right]$ & $93.656(6)$ & 120 & $97.44(2)$ \\
\hline$V\left[\AA^{3}\right]$ & $9667.3(16)$ & $3953.49(5)$ & $2404.9(12)$ \\
\hline$Z^{2}+1+2$ & 4 & 3 & 2 \\
\hline$D_{\text {calcd. }}\left[\mathrm{Mg} \mathrm{m}^{-3}\right]$ & 1.772 & $1.496^{[\mathrm{a}]}$ & 1.620 \\
\hline$\mu\left[\mathrm{mm}^{-1}\right]$ & 3.545 & $3.006^{[\mathrm{a}]}$ & 4.054 \\
\hline Absorption correction & analytical & multi-scan & analytical \\
\hline Absorption correction range & $0.36-0.81$ & $0.45-0.63$ & $0.11-0.83$ \\
\hline$(\sin \theta / \lambda)_{\max }\left[\AA^{-1}\right]$ & 0.61 & 0.61 & 0.48 \\
\hline No. of measured reflns & 100932 & 62695 & 19594 \\
\hline No. of independent reflns & 34944 & 5001 & 4453 \\
\hline$R_{1}^{[\mathrm{b}]} / w R_{2}^{[\mathrm{c}]}[I>2 \sigma(I)]$ & $0.0465 / 0.0965$ & $0.0253 / 0.0609$ & $0.0726 / 0.1814$ \\
\hline$R_{1}^{[\mathrm{b}]} / w R_{2}{ }^{[\mathrm{c}]}$ (all refl.) & $0.0691 / 0.1050$ & $0.0284 / 0.0619$ & $0.0831 / 0.1904$ \\
\hline$S^{[\mathrm{d}]}$ & 1.162 & 1.104 & 1.110 \\
\hline No. of refined parameters & 1873 & 212 & 489 \\
\hline No. of restraints & 195 & 0 & 300 \\
\hline Flack $x$ parameter & - & $0.008(14)$ & - \\
\hline
\end{tabular}

[a] Derived parameters do not contain the contribution of the disordered solvent. [b] $R=\Sigma\left(\left\|F_{\mathrm{o}}|-| F_{\mathrm{c}}\right\|\right) / \Sigma\left|F_{\mathrm{o}}\right| .[\mathrm{c}] w R_{2}=\left\{\Sigma\left[w\left(F_{\mathrm{o}}{ }^{2}-\right.\right.\right.$ $\left.\left.\left.F_{\mathrm{c}}\right)^{2}\right] / \Sigma\left[w\left(F_{\mathrm{o}}\right)^{2}\right]\right\}^{1 / 2}$. [d] $S=\left\{\Sigma\left[w\left(F_{\mathrm{o}}{ }^{2}-F_{\mathrm{c}}{ }^{2}\right)^{2}\right] /(n-p)\right\}^{1 / 2}$.

$411 \mathrm{w}, 328 \mathrm{~m} \mathrm{~cm}^{-1} .{ }^{1} \mathrm{H}$ NMR $\left(300.13 \mathrm{MHz},\left[\mathrm{D}_{6}\right] \mathrm{dmso}, 298 \mathrm{~K}\right): \delta=$ 7.49 (m, $6 \mathrm{H}$, Ph-ortho-H), 7.34 (m, $6 \mathrm{H}$, Ph-meta-H), 7.28 (m, 3 $\mathrm{H}, \mathrm{Ph}$-para-H), 4.04 (s, $\left.6 \mathrm{H}, \mathrm{Ph}-\mathrm{CH}_{2}-\mathrm{S}\right), 2.25\left[\mathrm{~s}, 6 \mathrm{H}, \mathrm{C}\left(\mathrm{CH}_{3}\right)_{2}-\mathrm{CH}_{2}-\right.$ $\mathrm{S}], 1.42\left(\mathrm{~s}, 18 \mathrm{H}, \mathrm{CH}_{3}\right)$ ppm. $\mathrm{C}_{33} \mathrm{H}_{45} \mathrm{Br}_{3} \mathrm{Ni}_{2} \mathrm{~S}_{6} \mathrm{Zn}$ (1056.6): calcd. C 37.51, H 4.29, Ni 11.11, S 18.21, Zn 6.19; found: calcd. C 37.92, H 4.41, Ni 11.61, S 17.13, Zn 6.67.

$\left[\mathrm{Ni}_{3}(\mathbf{x b s m s})_{2}\left(\mathrm{ZnBr}_{3}\right)_{2}\right] \mathbf{( 4 )}: \mathrm{ZnBr}_{2}(0.23 \mathrm{~g}, 1.0 \mathrm{mmol})$ in $50 \mathrm{~mL}$ of $\mathrm{CH}_{3} \mathrm{CN}$ was slowly added to a solution of [Ni(xbsms)] $(0.4 \mathrm{~g}$, $1.0 \mathrm{mmol}$ ) in $100 \mathrm{~mL}$ of $\mathrm{CH}_{3} \mathrm{CN}$. The colour changed from dark green to dark brown and the solution was stirred for $20 \mathrm{~h}$. A palebrown product $(0.415 \mathrm{~g})$ was collected by filtration and recrystallised from $\mathrm{dmf} /$ diethyl ether. After $2 \mathrm{~d}$, a brown precipitate was collected by filtration in a yield of $0.11 \mathrm{~g}(22 \%)$. IR: $\tilde{\mathrm{v}}_{\max }=2960 \mathrm{~m}$, $2925 \mathrm{~m}, 1647 \mathrm{vs}, 1490 \mathrm{w}, 1456 \mathrm{~m}, 1436 \mathrm{~m}, 1383 \mathrm{~s}, 1371 \mathrm{~s}, 1252 \mathrm{~m}$, 1137 m, 1115 m, 1088 m, 957 w, 865 w, 774 s, 688 m, 658 m, 606 w, $492 \mathrm{w}, 467 \mathrm{w} \mathrm{cm}^{-1} .{ }^{1} \mathrm{H}$ NMR $\left(300.13 \mathrm{MHz},\left[\mathrm{D}_{6}\right] \mathrm{dmso}, 298 \mathrm{~K}\right): \delta=$ $7.34(\mathrm{~m}, 8 \mathrm{H}, \mathrm{Ph}), 4.10\left(\mathrm{~s}, 8 \mathrm{H}, \mathrm{Ph}-\mathrm{CH}_{2}-\mathrm{S}\right), 2.00\left[\mathrm{~s}, 8 \mathrm{H}, \mathrm{C}_{\left(\mathrm{CH}_{3}\right)_{2}-}\right.$ $\mathrm{CH}_{2}$-S], 1.65 (s, $24 \mathrm{H}, \mathrm{CH}_{3}$ ) ppm. $\mathrm{C}_{32} \mathrm{H}_{48} \mathrm{Br}_{6} \mathrm{Ni}_{3} \mathrm{~S}_{8} \mathrm{Zn}_{2}(1475.6)+$ DMF: calcd. C 27.15, H 3.58, N 0.90, Ni 11.37, S 16.56, Zn 8.44; found C 28.19, H 3.66, N 1.10, Ni 11.82, S 16.81, Zn 8.40.

Crystal Structure Determinations: X-ray intensities were measured with a Nonius KappaCCD diffractometer with rotating anode and graphite monochromator $(\lambda=0.71073 \AA$ ) at a temperature of 150 (2) K. Numerical data and details of the data collection and refinement are presented in Table 5. The structures were solved by direct methods (SHELXS-97[31] for compounds 1 and 3; SIR-97[32] for compound 2) and refined with SHELXL97 against $F^{2}$ of all reflections. ${ }^{[31]}$ Non-hydrogen atoms were refined freely with anisotropic displacement parameters; hydrogen atoms were refined as rigid groups. Molecular illustrations, structure checking and calculations were performed with the PLATON package. ${ }^{[33]}$ CCDC-
612515 (1), -612516 (2), and -612517 (3) contain the supplementary crystallographic data for this paper. These data can be obtained free of charge from the Cambridge Crystallographic Data Centre via www.ccdc.cam.ac.uk/data_request/cif. 1: The diethyl ether solvent molecule was refined with an occupancy of 0.9 . 2: The crystal structure contains large, solvent-accessible channels along the $3_{2}$ screw axis (1078.9 $\AA^{3}$ per unit cell) filled with disordered solvent molecules. Their contribution to the structure factors was secured by back Fourier transformation using the SQUEEZE routine of the program PLATON, ${ }^{[33]}$ amounting to 267 electrons in the unit cell. 3: The crystal appeared to be non-merohedrally twinned with a $180^{\circ}$ rotation about $u v w=[100]$ as the twin operation. Additionally, there was a large anisotropic mosaicity about $h k l=(100)$ present. The intensity data were evaluated with EvalCCD. ${ }^{[34]}$ The twin refinement ${ }^{[35]}$ resulted in a twin fraction of $0.331(3)$.

\section{Acknowledgments}

These investigations were supported in part (M. L. and A. L. S.) by the Netherlands Foundation for Chemical Research, with financial aid from the Netherlands Organisation of Scientific Research (CWNWO). C. T. (University of Strasbourg) was involved in the project through the Socrates student exchange programme. The authors thank Prof. Dr. Jan Reedijk for stimulating discussions.

[1] C. L. Drennan, T. I. Doukov, S. W. Ragsdale, J. Biol. Inorg. Chem. 2004, 9, 511-515.

[2] T. I. Doukov, T. M. Iverson, J. Seravalli, S. W. Ragsdale, C. L. Drennan, Science 2002, 298, 567-572. 
[3] C. Darnault, A. Volbeda, E. J. Kim, P. Legrand, X. Vernede, P. A. Lindahl, J. C. Fontecilla-Camps, Nat. Struct. Biol. 2003, 10, 271-279.

[4] R. Krishnan, J. K. Voo, C. G. Riordan, L. Zahkarov, A. L. Rheingold, J. Am. Chem. Soc. 2003, 125, 4422-4423.

[5] R. C. Linck, C. W. Spahn, T. B. Rauchfuss, S. R. Wilson, J. Am. Chem. Soc. 2003, 125, 8700-8701.

[6] M. L. Golden, M. Rampersad, J. H. Reibenspies, M. Y. Darensbourg, Chem. Commun. 2003, 1824-1825.

[7] P. V. Rao, S. Bhaduri, J. Jiang, R. H. Holm, Inorg. Chem. 2004, 43, 5833-5849.

[8] T. C. Harrop, M. M. Olmstead, P. K. Mascharak, J. Am. Chem. Soc. 2004, 126, 14714-14715.

[9] R. Krishnan, C. G. Riordan, J. Am. Chem. Soc. 2004, 126, $4484-4485$.

[10] A. J. Amoroso, S. S. M. Chung, D. J. E. Spencer, J. P. Danks, M. W. Glenny, A. J. Blake, P. A. Cooke, C. Wilson, M. Schröder, Chem. Commun. 2003, 2020-2021.

[11] Q. Wang, A. J. Blake, E. S. Davies, E. J. L. McInnes, C. Wilson, M. Schröder, Chem. Commun. 2003, 3012-3013.

[12] M. L. Golden, C. M. Whaley, M. V. Rampersad, J. H. Reibenspies, R. D. Hancock, M. Y. Darensbourg, Inorg. Chem. 2005, 44, 875-883.

[13] T. Konno, M. Usami, M. Hirotsu, T. Yoshimura, T. Kawamoto, Chem. Commun. 2004, 2296-2297.

[14] M. L. Golden, S. P. Jeffery, M. L. Miller, J. H. Reibenspies, M. Y. Darensbourg, Eur. J. Inorg. Chem. 2004, 231-236.

[15] J. A. W. Verhagen, M. Beretta, A. L. Spek, E. Bouwman, Inorg Chim. Acta 2004, 357, 2687-2693.

[16] M. L. Miller, S. A. Ibrahim, M. L. Golden, M. Y. Darensbourg, Inorg. Chem. 2003, 42, 2999-3007.

[17] E. Bouwman, R. K. Henderson, A. L. Spek, J. Reedijk, Eur. J. Inorg. Chem. 1999, 217-219.

[18] V. E. Kaasjager, R. K. Henderson, E. Bouwman, M. Lutz, A. L. Spek, J. Reedijk, Angew. Chem. Int. Ed. 1998, 37, 16681670.

[19] M.-C. Chalbot, A. M. Mills, A. L. Spek, G. J. Long, E. Bouwman, Eur. J. Inorg. Chem. 2003, 453-457.
[20] Q. Wang, J. E. Barclay, A. J. Blake, E. S. Davies, D. J. Evans, A. C. Marr, E. J. L. McInnes, J. McMaster, C. Wilson, M. Schröder, Chem. Eur. J. 2004, 10, 3384-3396.

[21] D. R. Winge, C. T. Dameron, G. N. George, I. J. Pickering, I. G. Dance, in Bioinorganic Chemistry of Copper (Eds.: K. D. Karlin, Z. Tyeklár), Chapman \& Hall, New York 1993, vol. 1, p. $110-123$.

[22] M. Baumgartner, H. Schmalle, E. Dubler, Inorg. Chim. Acta 1993, 208, 135-143.

[23] V. E. Kaasjager, E. Bouwman, S. Gorter, J. Reedijk, C. A. Grapperhaus, J. H. Reibenspies, J. J. Smee, M. Y. Darensbourg, A. Derecskei-Kovacs, L. M. Thomson, Inorg. Chem. 2002, 41, $1837-1844$.

[24] V. E. Kaasjager, J. van den Broeke, R. K. Henderson, W. J. J. Smeets, A. L. Spek, W. L. Driessen, E. Bouwman, J. Reedijk, Inorg. Chim. Acta 2001, 316, 99-104.

[25] V. E. Kaasjager, L. Puglisi, E. Bouwman, W. L. Driessen, J. Reedijk, Inorg. Chim. Acta 2000, 310, 183-190.

[26] J. A. W. Verhagen, D. D. Ellis, M. Lutz, A. L. Spek, E. Bouwman, J. Chem. Soc., Dalton Trans. 2002, 1275-1280.

[27] J. A. W. Verhagen, Ph.D. Thesis, Leiden University, Leiden, 2004.

[28] J. A. W. Verhagen, M. Lutz, A. L. Spek, E. Bouwman, Eur. J. Inorg. Chem. 2003, 3968-3974.

[29] G. A. Bowmaker, G. R. Clark, J. K. Seadon, Polyhedron 1984, 3, 535-544.

[30] C. P. Rao, J. R. Dorfman, R. H. Holm, Inorg. Chem. 1986, 25 , 428-439.

[31] G. M. Sheldrick, University of Göttingen, Germnay, 1997.

[32] A. Altomare, M. C. Burla, M. Camalli, G. L. Cascarano, C. Giacovazzo, A. Guagliardi, A. G. G. Moliterni, G. Polidori, R. Spagna, J. Appl. Crystallogr. 1999, 32, 115-119.

[33] A. L. Spek, J. Appl. Crystallogr. 2003, 36, 7-13.

[34] A. J. M. Duisenberg, L. M. J. Kroon-Batenburg, A. M. M. Schreurs, J. Appl. Crystallogr. 2003, 36, 220-229.

[35] R. Herbst-Irmer, G. M. Sheldrick, Acta Crystallogr., Sect. B 1998, 54, 443-449.

Received: July 10, 2006 Published Online: October 10, 2006 